\title{
Effect of Bensulfuron methyl, Glyphosate and Glufosinate on Amino Acid and Ammonia Levels in Carrot Cells
}

\author{
Kenji Usui*, Srisom Suwanwong*, Hiroyuki Watanabe*,** \\ and Kozo Ishizuka*
}

\begin{abstract}
Normal carrot cell suspension treated with BSM showed changes in the free amino acid levels. Most of the amino acids either increased or remained constant, but the levels of valine and leucine decreased markedly. The level of isoleucine was significantly unchanged. In BSM-tolerant cells the free amino acid levels were not decreased. Exogenously supplying these three amino acids to normal cells provided the most effective recovery of growth inhibition.
\end{abstract}

Normal cells treated with GLY showed changes in the free amino acid levels. Most of the amino acids either increased or remained constant. The tolerant cells had higher levels of phenylalanine and tyrosine than that of normal cells. The combination of phenylalanine, tyrosine and tryptophan showed the best recovery of GLY-induced growth inhibition.

In GLU-tolerant cell suspensions, the GLUtreated normal cells had a high level of accumulated ammonia whereas , the tolerant cells did not. GLU-induced growth inhibition was recovered by glutamine incorporation.

Exposure to GLU had no effect on ammonia

Parts of this study were reported at the 29 th annual meeting of the Weed Science Society of Japan in April, 1990.

* Institute of Applied Biochemistry, University of Tsukuba, Tsukuba-shi, Ibaraki 305.

** Present address: Research Center, Mitsubishi Chemical Ind. Ltd., 1000 Kamoshida, Midoriku, Yokohama 227.

(Received September 21, 1990) accumulation in tolerant cells, suggesting that these cells may have an effective mechanism to avoid a high intracellular ammonia level.

Based on these findings, the high level of valine, leucine and isoleucine in BSM-tolerant cells; phenylalanine, tyrosine in GLY-tolerant cells; and glutamine in GLU-tolerant cells may be the result of adequate synthesis supported by overproduction of the target enzyme and/or production of a target enzyme insensitive to the herbicide which is involved in the tolerance mechanism.

Key words: bensulfuron methyl, glyphosate, glufosinate, amino acid levels, carrot cells

\section{Introduction}

The inhibition of amino acid biosynthesis is a well established target for herbicidally active compounds. To date, inhibition of only 5 of ca. 75 enzymes has been shown to have an herbicidal effect ${ }^{8}$. Three enzymes, acetolactate synthase (ALS), 5-enolpyruvylshikimate3-phosphate synthase (EPSP synthase) and glutamine synthetase (GS), have been well documented as the primary sites of action of the commercial herbicides, bensulfuron methyl (BSM), glyphosate (GLY) and glufosinate (GLU). These herbicides are active by interrupting the nitrogen metabolism in plants. BSM and GLY are highly potent inhibitors of the enzyme for branched-chain amino acids and aromatic amino acid biosynthesis, and 
GLU is an inhibitor of the enzyme for glutamine synthesis. We earlier reported on the selection of cells tolerant to these herbicides and on amino acid levels and GS activity in GLU-tolerant cells in relation to the tolerance mechanism ${ }^{10 \sim 12)}$. In this study using these herbicides to reveal the tolerance mechanism of the tolerant cells, effects of these herbicides on amino acid and ammonia levels were investigated.

\section{Materials and Methods}

\section{Cell Suspension Culture}

Cell suspensions induced from hypocotyl of carrot (Daucus carota L. cv. Harumakigosun) were cultured in Linsmaier and Skoog's medium (LS-medium) ${ }^{6)}$ containing $1 \mathrm{mg} / l 2,4-\mathrm{D}$ by subculturing at 7 -day intervals as previously described ${ }^{10)}$.

The BSM-tolerant carrot cells, GLY-tolerant cells and GLU-tolerant cells, capable of growth in the presence of $10^{-8} \mathrm{M}, 10^{-3} \mathrm{M}$ and $10^{-5} \mathrm{M}$ of BSM, GLY and GLU, respectively, were selected from untreated-normal cells through exposure to progressively higher concentrations of the herbicide ${ }^{10)}$, and thus had several hundred times more tolerance than the initial untreated cells. These cells are referred to as "BSM-tolerant, GLY-tolerant and GLU-tolerant" cells and untreated cells as "normal" cells in this experiment.

Cells at linear growth phase were harvested 4 days after the subculture for experimental purposes.

\section{Chemicals}

The BSM (over 99\% pure), GLY (44.7\% ae, isopropylamine form) and GLU (94. $4 \%$ pure, ammonium salt form) were the gifts of Du Pont Japan, Ltd., Monsanto Japan, Ltd. and Hoechst Japan, Ltd. These were dissolved in LS-medium at the respective concentrations of $10^{-4}, 10^{-1}, 10^{-2} \mathrm{M}$ and sterilized by mem- brane filter for stock solutions.

Ammonia Accumulation and Amino Acid Determination

Normal and tolerant cell suspensions at the linear growth phase were treated with BSM, GLY and GLU to give a final concentration of $10^{-8} \mathrm{M}$ BSM, $10^{-3} \mathrm{M}$ GLY and $10^{-6}, 10^{-5}$, $10^{-4} \mathrm{M}$ GLU. Sampling times were $0,1,2$, and 3 days after treatment.

Ammonia accumulation and amino acid content in cells were determined as previously described $^{11)}$. The cells were extracted with $10 \mathrm{mM} \mathrm{HCl}(1: 6 \mathrm{w} / \mathrm{v})$. The deproteinized supernatants were used for the determinations.

Ammonia was determined by Weatherburn's method $^{13)}$. Amino acids were determined using an amino acid analyzer (Hitachi, Model 835). Tryptophan could not be determined under these experimental conditions.

Recovery of Growth Inhibition by Amino Acid Incorporation

Normal cell suspensions were treated with $10^{-8} \mathrm{M}$ BSM, $10^{-3} \mathrm{M}$ GLY or $10^{-5} \mathrm{M}$ GLU and were added with valine, leucine, isoleucine; phenylalanine, tyrosine, tryptophan; and glutamine, respectively. All amino acids were used at $1 \mathrm{mM}$. Packed cell volume and cell weight were determined using duplicate flasks every 2 days.

\section{Results}

\section{Effect of BSM on Amino Acid Biosyn- thesis}

The level of 18 amino acids was determined in both normal and tolerant cells from the linear growth phase for a culture maintained in the medium with and without BSM (Table 1).

Since BSM inhibits ALS, the enzyme for branched-chain amino acid biosynthesis, the levels of valine and leucine in normal cells 
Table. 1. The effect of BSM on the levels of amino acids in normal and BSM-tolerant cells.

\begin{tabular}{|c|c|c|c|c|c|c|c|c|c|c|c|c|c|c|}
\hline \multirow{4}{*}{$\begin{array}{l}\text { Days } \\
\text { Amino } \\
\text { acid }\end{array}$} & \multicolumn{14}{|c|}{ Amino acid ( $\mu$ mole/g fresh weight $)$} \\
\hline & \multicolumn{7}{|c|}{ Normal cell } & \multicolumn{7}{|c|}{ Tolerant cell } \\
\hline & \multirow[t]{2}{*}{0} & \multicolumn{2}{|l|}{1} & \multicolumn{2}{|c|}{2} & \multicolumn{2}{|l|}{3} & \multirow[t]{2}{*}{0} & \multicolumn{2}{|c|}{1} & \multicolumn{2}{|c|}{2} & \multicolumn{2}{|l|}{3} \\
\hline & & $-\mathrm{BSM}$ & $+\mathrm{BSM}$ & $-\mathrm{BSM}$ & $+\mathrm{BSM}$ & $-\mathrm{BSM}$ & $+\mathrm{BSM}$ & & $-\mathrm{BSM}$ & $+\mathrm{BSM}$ & $-\mathrm{BSM}$ & $+\mathrm{BSM}$ & $-\mathrm{BSM}$ & $+\mathrm{BSM}$ \\
\hline Gln & 1.49 & 2. 64 & 3. 78 & 3. 62 & 8. 46 & 5.26 & 8. 92 & 1.45 & 2.43 & 1.89 & 2.85 & 2. 04 & 3.25 & 4. 10 \\
\hline Glu & 4. 34 & 6. 33 & 8. 54 & 7.23 & 9.12 & 7. 97 & 9.28 & 6. 30 & 7. 75 & 6. 40 & 7. 05 & 6.29 & 7. 04 & 6. 78 \\
\hline Pro & 0.94 & 1.14 & 2.61 & 1.99 & 3. 23 & 2.14 & 3.79 & 2. 72 & 1. 32 & 2. 29 & 1.13 & 1.48 & 1.15 & 1. 21 \\
\hline Arg & 0.15 & 0.10 & 0.14 & 0.16 & 0.14 & 0.64 & 0.15 & 0.30 & 0.68 & 0.58 & 5. 37 & 4. 68 & 7. 17 & 8. 19 \\
\hline Asn & 0.65 & 0.69 & 2.50 & 0.89 & 3. 40 & 1.12 & 4.68 & 0.48 & 0.54 & 0.54 & 0.99 & 0.93 & 1.15 & 1.33 \\
\hline Asp & 0.60 & 0.62 & 0.83 & 0.54 & 0.94 & 0.48 & 0.96 & 0.60 & 0.50 & 0.40 & 0.52 & 0.43 & 0.63 & 0.38 \\
\hline Thr & 0.35 & 0.26 & 0.84 & 0.32 & 1.13 & 0.38 & 1.37 & 0.39 & 0.33 & 0.38 & 0.50 & 0.56 & 0.59 & 0.70 \\
\hline Met & 0.05 & 0.04 & 0.03 & 0.04 & 0.02 & 0.05 & 0.02 & 0.08 & 0.07 & 0.09 & 0.10 & 0.13 & 0.14 & 0.15 \\
\hline Lys & 0.18 & 0.15 & 0.20 & 0.20 & 0.21 & 0.24 & 0.21 & 0.40 & 0.32 & 0.37 & 0.56 & 0.61 & 0.67 & 0.86 \\
\hline Val & 0.60 & 0.50 & 0.08 & 0.58 & 0.08 & 0.58 & 0.11 & 1.82 & 1. 69 & 2.25 & 1.37 & 2. 19 & 1.33 & 2. 19 \\
\hline Leu & 0.29 & 0.15 & 0.08 & 0.19 & 0.08 & 0.20 & 0.10 & 0.60 & 0.46 & 0.66 & 0.54 & 0.77 & 0.55 & 0.82 \\
\hline Ile & 0.19 & 0.12 & 0.12 & 0.14 & 0.14 & 0.17 & 0.16 & 0.32 & 0.25 & 0.31 & 0.42 & 0.44 & 0.41 & 0.47 \\
\hline Phe & 0.10 & 0.05 & 0.07 & 0.08 & 0.05 & 0.10 & 0.06 & 0.26 & 0.16 & 0.22 & 0.21 & 0.26 & 0.20 & 0.27 \\
\hline Tyr & 0.11 & 0.06 & 0.12 & 0.08 & 0.12 & 0.09 & 0.12 & 0.20 & 0.17 & 0.22 & 0.31 & 0.34 & 0.36 & 0.46 \\
\hline Ser & 1.63 & 1.81 & 3. 26 & 1.92 & 3. 50 & 2.03 & 3. 05 & 2. 09 & 2.12 & 2.48 & 2.14 & 2. 37 & 2.15 & 2. 31 \\
\hline Gly & 0.82 & 0.46 & 0.63 & 0.59 & 0.57 & 0.56 & 0.66 & 2. 20 & 2. 00 & 1.95 & 1. 79 & 2. 04 & 1.61 & 1.78 \\
\hline His & 0.18 & 0.21 & 0.82 & 0.29 & 1.17 & 0.40 & 1.72 & 0.65 & 0.73 & 0.71 & 0.69 & 0.68 & 0.62 & 0.76 \\
\hline Ala & 7. 20 & 5.90 & 8. 46 & 6.37 & 8.44 & 7. 15 & 8. 37 & 9. 03 & 8. 61 & 8. 63 & 8.16 & 8. 02 & 6.92 & 6.87 \\
\hline Total & 20 & 21 & 33 & 25 & 41 & 29 & 44 & 30 & 30 & 31 & 35 & 35 & 36 & 40 \\
\hline
\end{tabular}

Table 2. The effect of GLY on the levels of amino acids in normal and GLY-tolerant cells.

\begin{tabular}{|c|c|c|c|c|c|c|c|c|c|c|c|c|c|c|}
\hline \multirow{4}{*}{$\begin{array}{l}\text { Days } \\
\text { Amino } \\
\text { acid }\end{array}$} & \multicolumn{14}{|c|}{ Amino Acid ( $\mu$ mole/g fresh weight) } \\
\hline & \multicolumn{7}{|c|}{ Normal cell } & \multicolumn{7}{|c|}{ Tolerant cell } \\
\hline & \multirow[t]{2}{*}{0} & \multicolumn{2}{|c|}{1} & \multicolumn{2}{|c|}{2} & \multicolumn{2}{|l|}{3} & \multirow[t]{2}{*}{0} & \multicolumn{2}{|c|}{1} & \multicolumn{2}{|c|}{2} & \multicolumn{2}{|c|}{3} \\
\hline & & $-G L Y$ & $+\mathrm{GLY}$ & $-\mathrm{GLY}$ & $+\mathrm{GLY}$ & - GLY & +GLY & & - GLY & $+\mathrm{GLY}$ & - GLY & + GLY & $-G L Y$ & $+\mathrm{GLY}$ \\
\hline Gln & 1.64 & 2.18 & 8.81 & 2.83 & 8. 80 & 8. 30 & 11.51 & 0.74 & 2. 35 & 2. 08 & 4.90 & 4. 02 & 6.24 & 4.81 \\
\hline Glu & 4.96 & 5.13 & 5. 63 & 5. 76 & 8. 08 & 7.89 & 10.31 & 2. 22 & 2. 29 & 1.33 & 4.12 & 2. 35 & 2. 71 & 1.32 \\
\hline Pro & 0.88 & 0.74 & 1.70 & 0.91 & 3. 06 & 2. 06 & 4.54 & 0.35 & 0.42 & 0.38 & 0.36 & 0.35 & 0.43 & 0.38 \\
\hline Arg & 0.16 & 0.08 & 0.14 & 0.10 & 0.24 & - $^{*}$ & 0.99 & 0.31 & 0.44 & 0.36 & 1.24 & 2.77 & 5.43 & 6.92 \\
\hline Asn & 0.66 & 0.37 & 1. 82 & 0.42 & 3. 64 & 2. 37 & 4. 40 & 0.29 & 0.57 & 0.48 & 0.67 & 0.92 & 1.53 & 1.60 \\
\hline Asp & 0.65 & 0.45 & 0.51 & 0.34 & 0.81 & 0.84 & 1.12 & 0.12 & 0.10 & 0.09 & 0.25 & 0.25 & 0.42 & 0.41 \\
\hline Thr & 0.36 & 0.21 & 0.69 & 0.12 & 1. 21 & 0.51 & 1.42 & 0.22 & 0.24 & 0.25 & 0.22 & 0.32 & 0.46 & 0.53 \\
\hline Met & 0.05 & 0.05 & 0.04 & 0.05 & 0.03 & 0.06 & 0.04 & 0.04 & 0.04 & 0.04 & 0.06 & 0.07 & 0.06 & 0.10 \\
\hline Lys & 0.27 & 0.13 & 0.23 & 0.16 & 0.24 & 0.37 & 0.34 & 0.30 & 0.33 & 0.34 & 0.36 & 0.50 & 0.40 & 0.84 \\
\hline Val & 0.63 & 0.50 & 0.81 & 0.61 & 1.03 & 0.61 & 1.06 & 0.58 & 0.87 & 0.86 & 0.78 & 0.72 & 0.81 & 0.80 \\
\hline Leu & 0.30 & 0.14 & 0.24 & 0.14 & 0.24 & 0.18 & 0.26 & 0.29 & 0.36 & 0.37 & 0.31 & 0.36 & 0.41 & 0.48 \\
\hline Ile & 0.19 & 0.10 & 0.19 & 0.12 & 0.20 & 0.16 & 0.21 & 0.19 & 0.19 & 0.20 & 0.19 & 0.25 & 0.29 & 0.34 \\
\hline Phe & 0.14 & 0.06 & 0.10 & 0.07 & 0.05 & 0.09 & 0.06 & 0.22 & 0.22 & 0.23 & 0.22 & 0.27 & 0.26 & 0.33 \\
\hline Tyr & 0.11 & 0.06 & 0.08 & 0.07 & 0.06 & 0.16 & 0.08 & 0.12 & 0.14 & 0.15 & 0.11 & 0.21 & 0.26 & 0.30 \\
\hline Ser & 1.76 & 1.67 & 3. 02 & 1.80 & 4. 15 & 2.27 & 4.23 & 1. 08 & 1.40 & 1.15 & 1. 74 & 1.63 & 1.57 & 1.44 \\
\hline Gly & 0.88 & 0.54 & 0.80 & 0.62 & 0.53 & 0.36 & 0.68 & 1.08 & 1.12 & 1.09 & 1.04 & 1.00 & 1.03 & 1. 05 \\
\hline $\mathrm{His}$ & 0.18 & 0.12 & 0.37 & 0.17 & 0.72 & 0.73 & 0.78 & 0.22 & 0.28 & 0.24 & 0.28 & 0.32 & 0.48 & 0.46 \\
\hline Ala & 7.67 & 5.58 & 7. 71 & 6.15 & 7.53 & 6,30 & 8.64 & 6.87 & 8. 95 & 7. 97 & 9. 86 & 8. 95 & 8. 20 & 7. 19 \\
\hline Total & 21 & 18 & 33 & 20 & 41 & 33 & 51 & 15 & 20 & 17 & 26 & 25 & 31 & 29 \\
\hline
\end{tabular}

* can not detect 


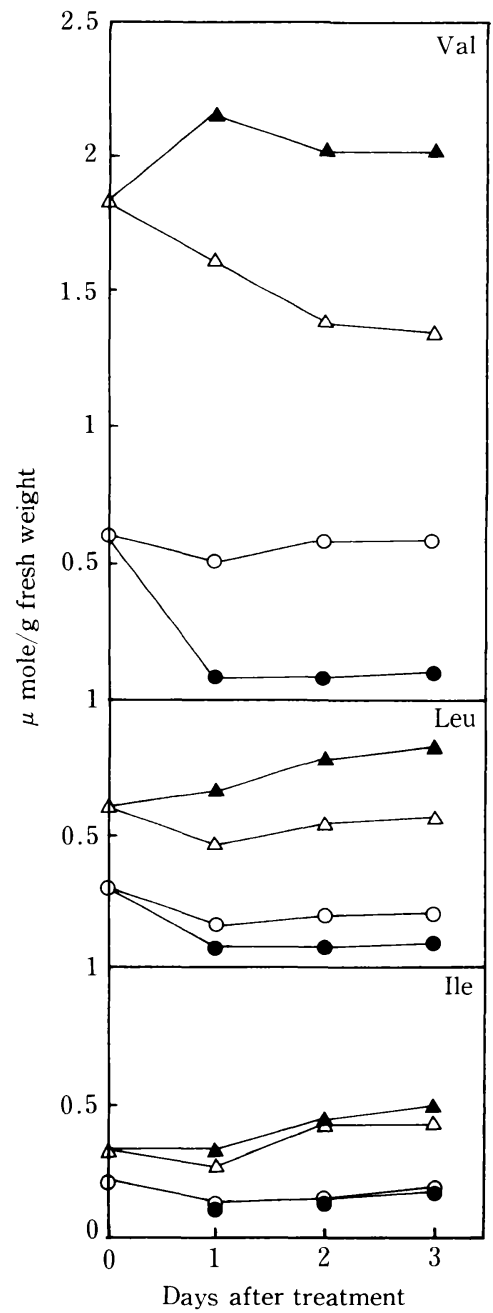

Fig. 1. Effect of BSM on the levels of valine leucine and isoleucine in normal and BSM-tolerant cells.

$O$ : Normal cells unexposed to BSM

: Normal cells exposed to BSM

$\triangle$ : Tolerant cells unexposed to BSM

$\Delta$ : Tolerant cells exposed to BSM

decreased markedly by $81-86 \%$ and $47-58 \%$ during the 3 days after treatment and those levels in tolerant cells were higher than normal cells in both cultures (Fig.1). With exposure to BSM, the levels of valine and leucine in tolerant cells were $20-28$ and 8-10 times higher than in normal cells.

With or without exposure to BSM, the level of isoleucine in both normal and tolerant cells was unchanged(Fig.1); however, the level in tolerant cells was higher than in normal cells.

Similar to isoleucine, the amount of glycine, arginine, lysine, phenylalanine, tyrosine and methionine in tolerant cells was higher than in normal cells in those both exposed and unexposed to BSM. However, the BSM had no effect on the levels of these amino acids in either cell type.

Total amount of the 18 amino acids increased substantially when normal cells were exposed to BSM. Amino acids primarily contributing to this increase were glutamic acid, glutamine, proline, asparagine and threonine. The percentage of total amino acids in BSMtreated normal cells was 57, 64 and 52\% higher than untreated normal cells at 1,2 and 3 days after treatment. With exposure to $\mathrm{BSM}$, the amount of total amino acids in tolerant cells was unchanged or only slightly increased.

The levels of other amino acids increased with the addition of BSM in normal cells, but were not affected in tolerant cells.

Effect of GLY on Amino Acid Biosynthesis

The levels of 18 amino acids were determined in both normal and tolerant cells from the linear growth phase for a culture maintained in medium with and without GLY (Table 2).

The total amount of the 18 amino acids increased substantially when normal cells were exposed to GLY. The major amino acids contributing to this increase were glutamic acid, glutamine, proline, asparagine, threonine and serine. The percentages of total amino acid in GLY-treated normal cells were 83, 105 and 54 higher than untreated normal cells at 1,2 and 3 days after treatment, respectively. The percentages of total amino acid in GLY-treated normal cells were 94, 64 and 


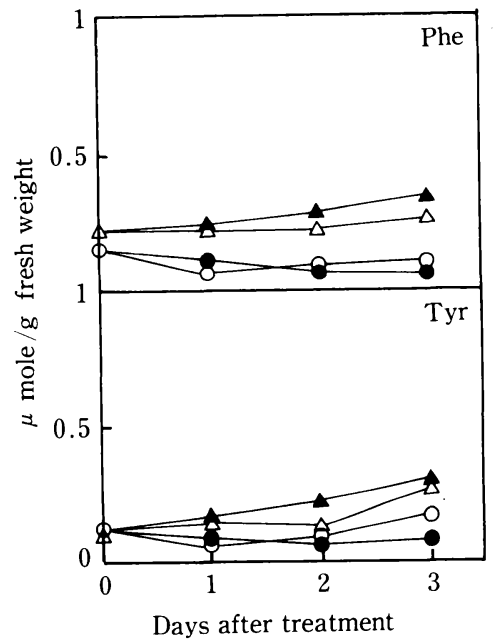

Fig. 2. Effect of GLY on the levels of phenylalanine and tyrosine in normal and GLY-tolerant cells.

$O$ : Normal cells unexposed to GLY

: Normal cells exposed to GLY

$\triangle$ : Tolerant cells unexposed to GLY

$\Delta$ : Tolerant cells exposed to GLY

$76 \%$ higher than treated-tolerant cells at 1,2 and 3 days after treatment.

The levels of phenylalanine and tyrosine in treated normal cells at 1 day after treatment were increased 2 and 1 fold over that of untreated normal cells (Fig.2). This is the same as reported by Dyer et al. ${ }^{3)}$ phenylalanine and tyrosine pools of GLY-sensitive tobacco cells were increased 5 and 2.5 fold, respectively.

Similar to findings by Nafziger et al. ${ }^{7)}$, at 2 and 3 days after treatment phenylalanine and tyrosine in normal cells were decreased by the addition of GLY (Fig.2). Methionine was also decreased.

In tolerant cells, GLY treatment caused little change in free amino acid levels, such as phenylalanine, tyrosine, proline as shown by Dyer et al. ${ }^{3}$. Methionine, threonine, histi dine, glycine, asparagine, aspartic acid, valine, leucine, isoleucine and lysine also remained unchanged. The GLY reduced glutamic acid, glutamine and alanine, and caused a slight decrease of serine in tolerant cells. Only the level of arginine in these cells was increased.

The tolerant cells had higher levels of free amino acids, especially phenylalanine, tyrosine, methionine and arginine than normal cells, similar to the report of Nafziger et al. ${ }^{7)}$, and glycine, leucine and lysine in tolerant cells were also higher. But the levels of threonine, histidine, serine, glutamic acid, glutamine, proline, asparagine and aspartic acid were lower in tolerant cells than in normal cells while alanine, valine and isoleucine were unchanged.

Effect of BSM, GLY and GLU on Ammonia Accumulation

The effect of BSM, GLY and GLU on ammonia content in the cells was investigated. The BSM and GLY did not much affect ammonia content in either normal or tolerant cells (data not shown). Ammonia accumulation in cells after the inhibition of GS activity by GLU is shown in Fig. 3. Ammonia did not accumulate in either cell type during the experiment unless exposed to GLU. Similarly, ammonia did not accumulate in treatedtolerant cells or in normal cells treated with $10^{-6} \mathrm{M}$ (Fig. 3a); but it did accumulate gradually with time of exposure in the $10^{-5}$ (Fig. $3 \mathrm{~b}$ ) and $10^{-4} \mathrm{M}$-treated normal cells (Fig. 3c). When normal cells were exposed to $10^{-5} \mathrm{M}$, ammonia content in treated cells was about 200 and $300 \mu \mathrm{g} \quad \mathrm{NH}_{3} / \mathrm{g}$ fresh weight, and that in $10^{-4} \mathrm{M}$-treated normal cells was about 200 and $400 \mu \mathrm{g} \quad \mathrm{NH}_{3} / \mathrm{g}$ fresh weight respectively 2 and 3 days after treatment.

Recovery of Growth Inhibition by Branched-chain Amino Acid Incorporation

Various combinations of the amino acids valine, leucine and isoleucine were applied to recover the cell growth inhibition caused by BSM.

The addition of the branched-chain amino 

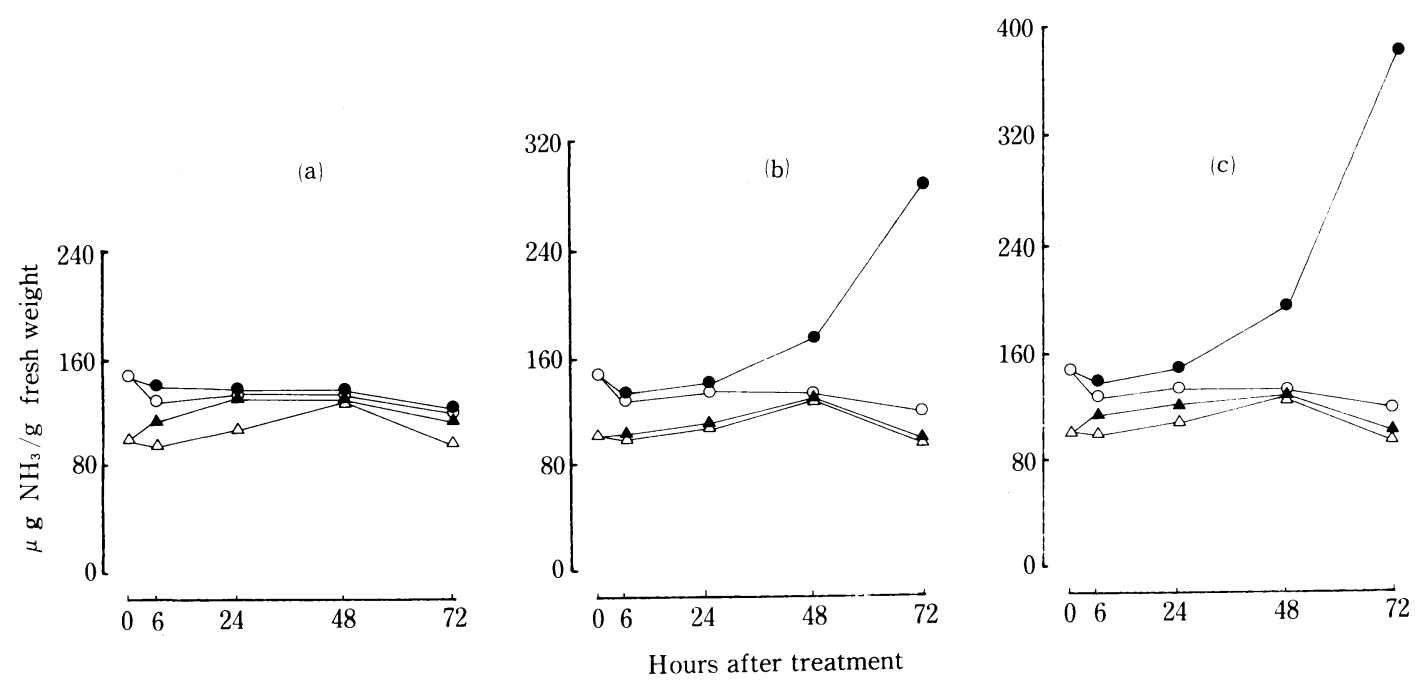

Fig. 3. Effect of GLU on ammonia accumulation in normal and GLU-tolerant cells.

(a. $10^{-6} \mathrm{M}$ GLU; b. $10^{-5} \mathrm{M}$ GLU; c. $10^{-4} \mathrm{M}$ GLU)

$O$ : Normal cells unexposed to GLU

: Normal cells exposed to GLU

$\triangle:$ Tolerant cells unexposed to GLU

$\Delta$ : Tolerant cells exposed to GLU

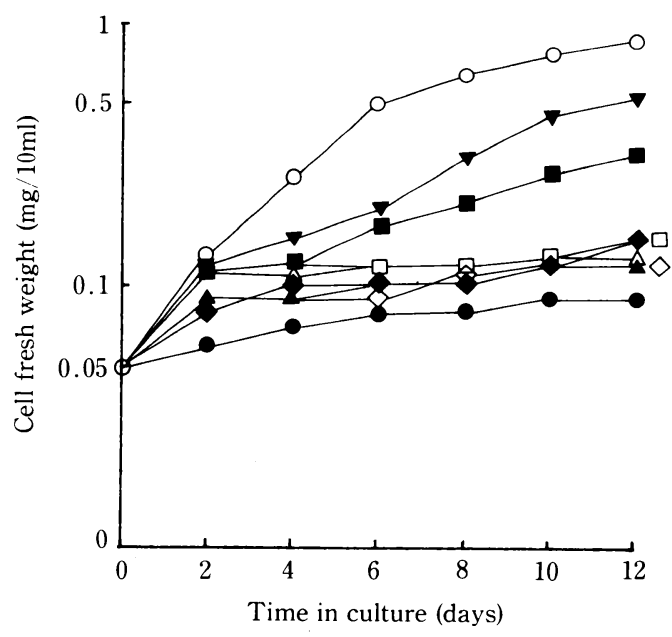

Fig. 4. Recovery of grow th inhibition in normal cells by $1 \mathrm{mM}$ amino acid incorporation.
O : Control
: BSM
$\triangle: \mathrm{BSM}+\mathrm{Val}$
$\diamond: \mathrm{BSM}+$ Leu
$\square: \mathrm{BSM}+\mathrm{Ile}$
$\mathbf{\Delta}:$ BSM+Val, Leu
: $\mathrm{BSM}+$ Val, Ile
$\boldsymbol{\text { }}: \mathrm{BSM}+\mathrm{Leu}$, Ile
: $\mathrm{BSM}+$ Val, Leu, Ile

acids and their combinations at $1 \mathrm{mM}$ showed that the combination of valine, leucine and isoleucine was the most effective (Fig.4). At $1 \mathrm{mM}$ amino acid treatment, the best two- amino acid combination was valine plus isoleucine. The inhibition was not recovered by either of the other two-amino acid combinations or by single amino acid treatment. The best recovery was achieved with a mixture of the three amino acids.

Recovery of Growth Inhibition by Aromatic Amino Acid Incorporation

The effect of single amino acids and their combination on the recovery of growth inhibition caused by GLY (Fig. 5) revealed that the best recovery was achieved with a mixture of phenylalanine, tyrosine and tryptophan. The inhibition was not recovered by any single amino acids or by their two-amino acid combinations.

Recovery of Growth Inhibition by Glu tamine Incorporation

The effect of glutamine on the recovery of growth inhibition of carrot cells was investigated (Fig. 6). Inhibition caused by GLU in cultured carrot cells was recovered by the addition of glutamine. 


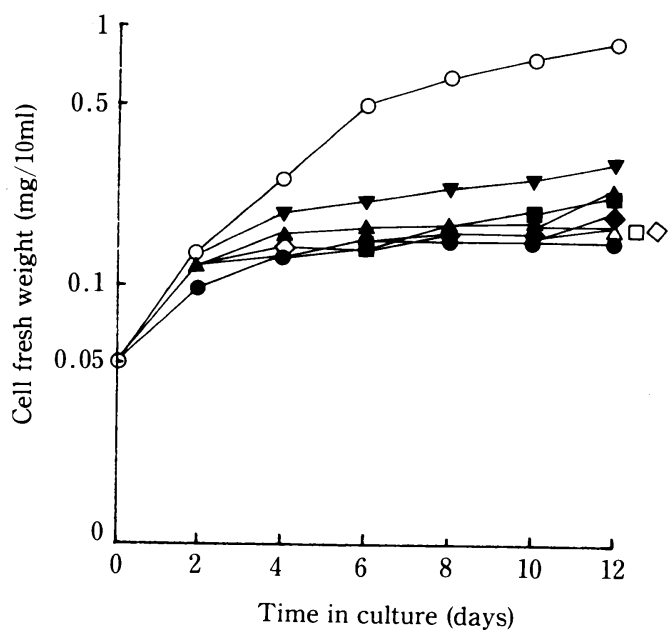

Fig. 5. Recovery of growth inhibition in normal cells by $1 \mathrm{mM}$ amino acid incorporation.

$\mathrm{O}:$ Control

$\begin{array}{ll}\bullet: \text { GLY } & \Delta G L Y+P h e, \text { Tyr } \\ \triangle: \text { GLY + Phe } & \text { GLY + Phe, Trp } \\ \diamond: \text { GLY + Tyr } & \text { GLY + Tyr, Trp } \\ \square: \text { GLY + Trp } & \nabla G L Y+P h e, \text { Tyr, Trp }\end{array}$

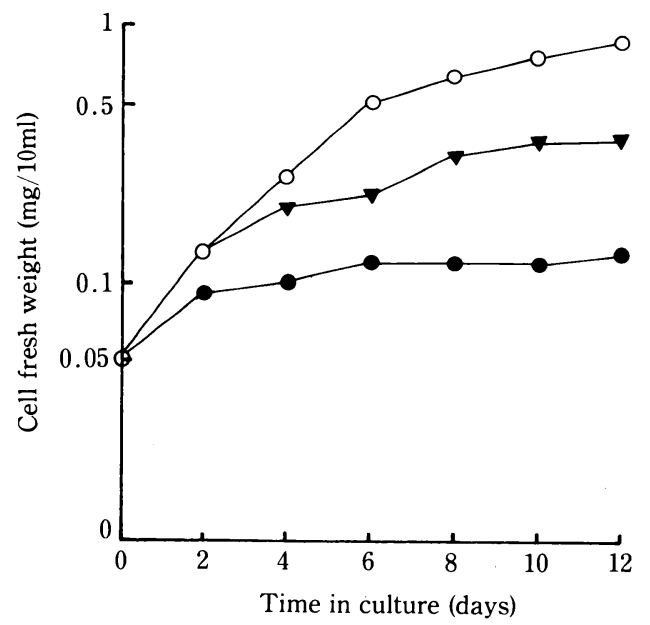

Fig. 6. Recovery of grow th inhibition in normal cells by $1 \mathrm{mM}$ glutamine incorporation.

$\mathrm{O}:$ Control, $: \mathrm{GLU}\left(10^{-5} \mathrm{M}\right), \boldsymbol{\nabla}: \mathrm{GLU}+\mathrm{Gln}$

Based on this finding, the high level of valine, leucine and isoleucine in BSM-tolerant cells; phenylalanine and tyrosine in GLYtolerant cells; and glutamine in GLU-tolerant cells may be the result of adequate synthesis supported by overproduction of the target enzyme and/or production of a target enzyme insensitive to the herbicide which is involved in the tolerance mechanism.

\section{Discussion}

BSM, GLY and GLU are highly potent inhibitors for amino acid biosynthesis. This inhibition is well known to be a target for herbicidal active compounds.

The effect of BSM on pool size of branchedchain amino acids showed that pool size of the biosynthetically related amino acids valine and leucine in normal cells was significantly reduced, while it was elevated in BSM-tolerant cells, similar to an earlier report ${ }^{4}$. The reduction of valine and leucine caused by BSM was the same as that by imidazolinone, an herbicide similar in mode of action to sulfonylurea, as reported by Anderson and Hibberd $^{1)}$. They also found that the amount of isoleucine in corn cell suspension cultures treated wtih imidazolinone was increased 2.4 times. In this report, the isoleucine content did not significantly change after BSM treatment in either normal or tolerant cells. Since BSM inhibits ALS and biosynthesis of valine, leucine and isoleucine ${ }^{9)}$, there may be a compensatory biosynthetic route of isoleucine.

The fact that media supplementation with valine, leucine and isoleucine will substantially alleviate growth inhibition of normal cells suggested that the primary toxic effect of BSM is on the branched-chain amino acid metabolism. It is possible that the BSM-induced amino acid deficiencies cause an inhibition of growth. It has recently been shown that treatments with branched-chain amino acids will also reverse the effect of the sulfonylurea herbicides, chlorsulfuron and sulfometuron methyl ${ }^{9)}$ and imidazolinone ${ }^{1)}$.

In this experiment, the GLY-tolerant cells had higher levels of free amino acids, especially phenylalanine, tyrosine, methionine and 
arginine than that of normal cells which was similar to the report of Nafziger et al. ${ }^{7}$. In addition, the GLY-induced growth inhibition was recovered by the addition of the aromatic amino acids. The high levels of the aromatic amino acids presumably provided protection against GLY. This generally supports the hypothesis that inhibition of aromatic amino acid biosynthesis is the primary mode of action of this herbicide.

The inhibition of GS by GLU causes an accumulation of ammonia and also a suppression of glutamine synthesis ${ }^{5}$. Owing to the inhibition of GS in normal cells, glutamine in these cells was remarkably lower ${ }^{11)}$. Glutamine is a primary product of ammonia assimilation and an important intermediate of various amino acids. Therefore, a lack of glutamine interferes with amino acid biosynthesis. In addition to the lack of glutamine, the total amount of free amino acids in normal cells was decreased as well as the levels of single amino acids such as alanine and valine ${ }^{11}$. The incorporation of glutamine reversed the growth inhibition induced by GLU. The large quantity of glutamine and low level of ammonia in the tolerant cells indicate a mechanism which effectively avoids intracellular ammonia accumulation. The dramatic decrease in glutamine induced by GLU ${ }^{11)}$, along with the increase in ammonia level, implies that normal cells may have a less effective means of protection against ammonia toxicity. As the GS activity in the tolerant cells was raised ${ }^{11)}$, ammonia did not accumulate in these cells even when treated with $10^{-4} \mathrm{M}$ of GLU. It seemed that the increased GS activity in tolerant cells prevented ammonia accumulation.

Acknowledgements: The authors would like to express their appreciation to $\mathrm{Dr}$. $\mathrm{H}$.
Kamada, University of Tsukuba, for his kindness in supplying induced carrot cells, to $\mathrm{Du}$ Pont Japan, Ltd., Monsanto Japan, Ltd., and Hoechst Japan, Ltd. for the gifts of technical grade herbicides and to Mr. H. Nakazono at the Chemical Analysis Center, University of Tsukuba for amino acid analyses.

\section{References}

1) Anderson, P.C. and K.A. Hibberd 1985. Evidence of the interaction of an imidazolinone herbicide with leucine, valine and isoleucine metabolism. Weed Sci. 33, 479-483.

2) Desmaison, A.M., M.H. Marcher and M. Tixier 1984. Changes in the free and total amino acid composition of ripening chestnut seeds. Phytochemistry 23(11), 2453-2456.

3) Dyer, W.E., S.C. Weller, R.A. Bressan and K.M. Hermann 1988. Glyphosate tolerance in tobacco (Nicotiana tabacum L.). Plant Physiol. 88, 661-666.

4) Ishizuka, K. and H. Watanabe 1988. Selection of carrot suspended cells resistant to DPX-F 5384 and their biochemical response. Proc. European Weed Research Soc. Symp. pp. 367-372.

5) Lea, P.J., K.W. Joy, J.L. Romos and M.G. Guerrero 1984. The action of 2-amino-4-(methylphosphinyl)butanoic acid (phosphinotrricin) and its 2-oxo-derivative on the metabolism of cyanobacteria and higher plants. Phytochemistry 23(1), 1-6.

6) Linsmaier, E.M. and F. Skoog 1965. Organic growth factor requirement of tobacco tissue culture. Physiol. Plant. 18, 100-127.

7) Nafziger, E.D., J.M. Widholm, H.C. Stein rucken and J.L. Killmer 1984. Selection and characterization of a carrot cell line tolerant to glyphosate. Plant Physiol. 76, 571-574.

8) Pillmoor, J.B. 1989. Amino acid biosynthesis- an Aladdin's cave of new pesticide target? in Prospects for Amino Acid Biosynthesis Inhibitors in Crop Protection and Pharmaceutical Chemistry, ed. L.G. Copping, J. Dalziel and A.D. Dodge. The Lavenham Press Limited, Lavenham, Suffolk. pp. 23-30.

9) Ray, T.B. 1984. Site of action of chlorsulfuron: Inhibition of valine and isoleucine biosynthesis in plants. Plant Physiol. 75, 827-831.

10) Suwanwong, S., K. Usui and K. Ishizuka 1989. Selection of tolerant cells from carrot suspension culture to bensulfuron methyl, glyphosate and glufosinate. Weed Res., Japan 34(4), 315-321.

11) Suwanwong, S., K. Usui and K. Ishizuka 1990. Glufosinate tolerance in carrot cell suspension cul- 
ture. Weed Res., Japan, 35(1), 53-60.

12) Watanabe, H., H. Hisamitsu and K. Ishizuka 1988. Selection of carrot cells tolerant to bensulfuron methyl and their acetolactate synthase response.
Weed Res., Japan 33(4), 285-292.

13) Weatherburn, M.W. 1967. Phenol-hy pochlorite reaction for determination of ammonia. Anal. Chem. 39, 971-974.
ベンスルフロンメチル, グリホサートおよびク ルホシネートのニンジン細胞のアミノ酸レベル に対する効果

白井健二*・スィーソム スワンウォン* 渡辺博之*・石塚晧造*

\section{摘 要}

ニンジン懸濁培養細胞に打ける除草剤耐性機構を細 胞内のアミノ酸拉よびアンモニアレベルを測定するこ とにより追究した。

分岐鎖アミノ酸(バリン, ロイシン，イソロイシン) 生合成を阻害するベンスルフロンメチル（BSM）を通 常細胞に処理すると, 細胞内の遊離フミノ酸レベルは 大部分が增加あるいは一定を維持したが，バリン，口 イシンが著しく減少した。耐性細胞では概して高いア ミノ酸レベルであったが, BSM 処理によりバリン, ロ イシンの増加が見られた。イソロイシンレベルはBSM 処理による変化がなかった(Table 1, Fig. 1)。また， 通常細胞の BSM による生育阻害は培地に上記 3 フミ ノ酸を添加すると最も効果的に回復した（Fig. 4)。 グリホサート (GLY) は, 芳香族アミノ酸 (フェニ ルフラニン, チロシン, トリプトフォン) の生合成を 阻害するが，その通常細胞への処理により芳香族アミ

* 筑波大学応用生物化学系
ノ酸の若干の減少のほかアミノ酸レベルに变動があっ た(Table 2, Fig. 2)。またGLYによる通常細胞の生育 阻害の回復にはフェニルアラニン, チロシン, トリプ トファンの組合せが最も有効であった（Fig. 5)。耐性 細胞では, 通常細胞よりフェニルフラニン, チロシン レベルが高く，GLY 処理により增加が見られた。

グルホシネート (GLU) 処理により通常細胞のグル タミンレベルが著しく減少することは既に報告した (Suwanwong et al. 1990)。GLU による通常細胞の 生育阻害はグルタ ミン添加により回復した（Fig. 6)。 また，GLU 処理により通常細胞では著しいアンモニ アの集積が見られたが，耐性細胞では見られなかった (Fig. 3)。このことは, 耐性細胞が高濃度に細胞内て ンモニアを蓄積しない有効な機構を有することを示唆 する。なお，BSM，GLY 処理では通常細胞で若干の アンモニア濃度の增加が見られたのみであった。

以上の結果より BSM 耐性細胞でのバリン，ロイシ ン, イソロイシンの, GLY 耐性細胞でのフェニルア ラニン, チロシンの, GLU 耐性細胞でのグルタミン の高いレベルは，標的醇素の過剩生産扰よび/あるい は，除草剤不感受性醅素の生成により支持された十分 な生合成の結果であり，これらが耐性機構に大きく関 係していると考えられる。

キーワード:ベンスルフロンメチル，グリホサート， グルホシネート，アミノ酸レベル，ニンジン細胞 